\title{
O ÚLTIMO TÍSICO: A IMAGEM DA TUBERCULOSE NA POESIA DE MANUEL BANDEIRA*
}

\author{
Rafael Soares de Oliveira ${ }^{* *}$
}

Resumo: Este artigo tem por objeto de estudo a imagem da tuberculose em textos poéticos de Manuel Bandeira, encarando-a não como tradução literária de um dado biográfico, mas sim como construção essencialmente artística, recolhida a um arsenal de temas e imagens marcadamente romântico-simbolista. Examinando-se poemas de Bandeira, à luz de dois textos de Cruz e Sousa, busca-se não apenas estabelecer a filiação romântico-simbolista do poeta moderno, mas também, em uiltima análise, demonstrar a importância da chamada mentalidade cristã para a concepção de mundo que se pode depreender de sua obra. Associando o afastamento do mundo à pureza (e, por conseqüiência, o mundo à impureza), a tuberculose aponta para a idéia dé redenção pela morte, capital para o cristianismo.

Jamais há de ter ela a cor saudável

Para que a carne do seu corpo goze,

Que o que tinha esse corpo de inefável

Cristalizou-se na tuberculose.

(Cruz e Sousa, "Tuberculosa")

\section{SOU ROMÂNTICO? CONCEDO. ${ }^{1}$}

Manuel Bandeira é, confessadamente, um herdeiro direto do Romantismo e do Simbolismo. É o que transparece de forma nítida em seus primeiros livros, especialmente em A Cinza das Horas, que, longe de se resumir a

\footnotetext{
- Recebido para publicação em agosto de 2006.

"Mestrando do Pós-Lit - Programa de Pós-Graduação em Letras - Estudos Literários da Faculdade de Letras/UFMG

'Manuel Bandeira, "Sextilhas Românticas".
} 
uma galvanização gratuita de trejeitos finisseculares, representa um prólogo à altura da obra que encabeça, fixando, desde si, a maneira de enxergar o mundo e de se relacionar com ele peculiar a essa obra. Assim, contrastando esse primeiro momento da poesia bandeiriana com os que o sucederam, não se percebe uma ruptura radical de iconoclasta ou mesmo qualquer tipo de descontinuidade, mas a mera evolução natural do estilo, advinda da adoção gradual de uma diç̧ão modernista — o que, por sua vez, também se dá sem qualquer trauma.

A idéia central deste estudo é se debruçar sobre o tema da tuberculose, em Bandeira, não como dado empírico de sua biografia ou mesmo como transposição da experiência real da doença para a poesia, mas como construção puramente literária, imagem poética para determinada visão de mundo, já, à época, de certa tradição na cultura ocidental, de que Bandeira se apropria sem grandes corrupções, embora a seu modo específico. Não se pretende recorrer à vida do poeta para elucidar sua poesia, nem especular sobre suas motivações pessoais para escrever da forma em que o fez, mas analisar o produto objetivo de seu trabalho, examinado-lhe as relações internas e implicações semânticas subjacentes, bem como a sua relação com a tradição literária de que descende.

Sob essa perspectiva, o tema da tuberculose, indício da ascendência simbolista de Manuel Bandeira, dá testemunho da relação sui generis entre esse poeta e os valores literários que o Modernismo, movimento em que se inscreve, surgiu para derrubar. Eqüidistante da combatividade niilista e do reacionarismo puro, Bandeira constitui caso inédito entre nossos modernistas, filiando-se confortavelmente à tradição, sem se eximir, contudo, de uma autoconsciência agudamente moderna.

Com efeito, ao se utilizar da imagem da tuberculose, Bandeira o faz segundo os preceitos consagrados pelo Romantismo e pelo Simbolismo. $\mathrm{O}$ que não se dá, contudo, pelo mero aproveitamento de chavões recorrentes em obras dessas escolas, mas pela afinidade íntima entre a poética bandeiriana e uma certa sensibilidade doentia, própria dos reclusos, comum àquelas escolas. A tuberculose, articulada dessa maneira, constitui, como dito anteriormente, um símbolo para um determinado modo de estar no mundo, situando-se, por isso, no cerne da poética bandeiriana. A recorrência do tema na obra do poeta atesta a afirmação. 
Como estratégia de estudo, serão examinados poemas de Manuel Bandeira que aludam à tuberculose ou contribuam para o delineamento mais preciso daquilo para que a tuberculose serve de emblema. Tal exame deverá ser feito à luz de dois outros poemas (da autoria de Cruz e Sousa), que constituem, talvez, a sintese mais sistemática dos valores e imagens associados à tuberculose, no âmbito da literatura nacional: "Tísica", poema em prosa publicado em Missais, e "Tuberculosa", publicado em Broquéis. Ademais, refletir-se-á sobre possiveis ligações entre a chamada mentalidade cristã e a imagem da tuberculose, na esperança de melhor definir a função desempenhada por esta na poesia de Bandeira.

\section{AQUÉM DA MORTE, PARA ALÉM DA VIDA}

A primeira alusão à tuberculose na obra de Manuel Bandeira se dá já em Cinza das Horas, em um soneto intitulado "a Antônio Nobre", o que, por si só, já sugere o vínculo dessa obra com o Simbolismo. Analogamente, no corpo do poema, o eu lírico afirma, comovido, o vínculo entre o seu destino pessoal e o do autor de Só, ambos condenados a "tossir bebendo o ar fino" e a "esmorecer e desejando tanto..." (BANDEIRA, 1970: 8). A proximidade desses dois dados dentro da estrutura da estrofe é uma pista valiosa sobre o significado aqui atribuído à tuberculose.

Observe-se que, enquanto, nos quartetos, o eu lírico e a figura de Antônio Nobre caminham lado a lado, irmanados pela condição singular de tuberculosos, a partir do verso 9 , seus caminhos se separam. O bom sucesso das esperanças de Nobre rompe a relação de especularidade perfeita desenvolvida entre este e o eu lírico, para quem a "Glória" (Idem) está perpetuamente vedada. A ligação entre os dois, urdida pela tísica, não sobrevive à realização das aspirações. Nessa sua primeira aparição, portanto, a doença se apresenta intimamente associada ao desejo frustrado.

O mesmo ocorrerá em "Pierrot Branco", poema de Carnaval, que explora o consagrado estereótipo da Commedia dell'Arte italiana, bem como em "Tema e Voltas", de Mafuá do Malungo. Porém, enquanto em "a Antônio Nobre", é a ânsia por glória e distinção que não se vê atendida, os dois poemas acima citados versam sobre a irrealização amorosa. "Tema e Voltas" se constitui na enunciação de uma série de atividades vitais a que o eu lírico não pode se 
entregar de corpo inteiro (embora o deseje) por causa da doença. Há destaque especial, contudo, para "de Eros a arte delicada" (BANDEIRA, 1970: 359), talvez a que melhor resuma a esfera de atividades vedada ao tuberculoso.

Verificando "Tísica" e "Tuberculosa" (respectivamente citadas abaixo), encontraremos a mesma associação entre tuberculose e desejo frustrado. Ambos os poemas têm por tema a metamorfose de jovens viçosas e cheias de vida em criaturas cinzentas, dessexualizadas. Vitimadas pela doença, elas como que se retiram do mundo, passando a habitar um plano insular e superior, num movimento análogo, talvez, à reclusão real dos tuberculosos. Tal movimento, contudo, encontra-se aqui completamente transfigurado, investido de um caráter místico e fantástico. Assim, roubadas ainda virgens à esfera mundana, as jovens tísicas se mineralizam ou vegetalizam, adquirindo uma aura lunar de santidade:

"Vejo-a continuamente de uma palidez clorótica, os olhos de um brilho cru, agudo, que faz febre; as orelhas diáfanas, muito despegadas do crânio; o nariz cada vez mais afilado e desfalecido; toda ela de uma amarelada transparência de morte, d'uma magreza hirta, como essas santas mártires do cilício que vivem nos claustros fechados e austeros de pedra, olhando entre grades para céus fuscos, com olhos cheios de fluidos místicos do Panteísmo, e que parecem subir, através de nimbos, além, às empíreas regiões dos excelsos arcanjos alvos de luz..." (SOUSA, 1998: 128)

"E faz lembrar uma esquisita planta

De profundos pomares fabulosos

Ou a angélica imagem de uma Santa

Dentre a auréola de nimbos religiosos."

(SOUSA, 1998: 176)

Logo percebemos que a frustração do desejo ganha, aqui, feições peculiares, que dizem muito da "visão tísica de mundo", por assim dizer, como ela se manifesta na poesia bandeiriana. A noção de isolamento e exterioridade em relação ao mundo e à vida é capital para a poética de Bandeira. De fato, 
tal poética parece se construir sempre do ponto de vista de quem observa sem participar, encontrando na imagem da tuberculose (colhida ao repertório romântico-simbolista) uma de suas formas de expressão mais poderosas. $\mathrm{Se}$, ao longo da "narrativa lírica", por assim dizer, que percorre toda a obra de Bandeira, o personagem principal se encontra apartado de seus semelhantes, a gênese dessa cisão está diretamente relacionada à fatalidade da doença. É o que indica "Pneumotórax", de Libertinagem.

Esse famoso poema narra o momento do desengano do eu lírico com relação às possibilidades de cura para sua doença. "Não há nada a fazer" - diz o médico; nem o último recurso da medicina é capaz de extirpar o mal fundamente entranhado em seu corpo (verso 8). Ele descobre que não tem tuberculose, simplesmente, mas é um tuberculoso. A doença é parte constitutiva de sua identidade, e, enquanto viver, carregará o seu estigma. Daí a cisão com o restante dos homens e com o mundo, "a vida inteira que podia ter sido e que não foi" (BANDEIRA, 1970: 107). Esse verso resume bem a singular esfera de existência em que a tuberculose situa o eu lírico: como que uma região além da vida, mas aquém da morte, que, como vimos, em Cruz e Sousa, associa-se à condição dos santos e das monjas enclausuradas. Despida dos ornamentos da mística cristã, essa sublimação simbolista se transforma em pura frustração, no poema de Bandeira.

À rejeição da retórica clássica do Simbolismo, entretanto, nem sempre corresponde um afastamento definitivo de seu aspecto ideológico (isto é, a mentalidade cristã). Disso dá prova o poema "Jaqueline", de Estrela da Manhã, que, embora não se refira propriamente à tuberculose, apropria-se de um motivo entranhadamente ligado ao da doença: o da "virgem morta" (de resto, bastante caro ao cânone romântico-simbolista). A morte precoce, interrompendo o fluxo da vida que conduz, inexoravelmente, à corrupção, exerce, sobre Jaqueline, um efeito análogo ao que a doença exercera sobre as protagonistas de "Tísica" e "Tuberculosa", coroando-a com o nimbo da pureza perene. Subjaz a essa imagem um cristianismo que, embora adaptado à modernidade atéia, permanece firme em seus valores fundamentais. Dessa forma, no próprio ato de negar a existência real aos anjos, o poema termina por reafirmar o poder santificador da morte: "Os anjos!... Bem sei que não os há em parte alguma. Há é mulheres extraordinariamente belas que morrem ainda meninas" (BANDEIRA, 1970: 143). 
Na verdade, nem mesmo seria legítimo dizer que são raros os momentos, na poesia de Bandeira, em que se associa a pureza ao afastamento do mundo e da vida — associação de teor marcadamente cristão. Verifique-se, a esse respeito, "Na Rua do Sabão", de O Ritmo Dissoluto. Aquele afastamento, nesse poema, está representado pela desarmonia patente entre a figura do menino tísico e o mundo ao seu redor. Susan Sontag, em $A$ Doença como Metáfora, afirma que a tuberculose é a doença que "põe uma pessoa em relevo contra 0 meio" (SONTAG, 1984: 49). Isso é especialmente verdadeiro em "Na Rua do Sabão". No entanto, a despeito da hostilidade que o cerca, o "balãozinho de papel" (BANDEIRA, 1970: 96) (verdadeiro protagonista do poema), como que animado pelo pneuma doentio do menino tísico e concentrando em si suas aspirações, consegue se libertar da prosaica "Rua do Sabão." (Idem) e vai se refundir com as "águas puras do mar alto" (Idem. Grifo meu).

A imagem do "mar alto", homogêneo e onímodo, bastante recorrente na obra de Bandeira, parece conter sempre uma certa sugestão de Uno Original, acentuada, nesse caso particular, pelo adjetivo "puras". A tensão entre 0 outsider tuberculoso e o mundo que o cerca, portanto, corresponde aqui ao contato do primeiro com algo maior e mais puro, algo que se encontra "muito longe" (Idem), a uma distância galgável apenas por um balão impelido por um "soprinho tísico" (Idem). De certa forma, é, então, a tuberculose a responsável pela ponte entre José e essa realidade outra. O que não causará espanto se levarmos adiante o paralelo entre "mar alto" e "paraíso perdido", posto que a única via de recondução a este último é a própria morte, identificada à tuberculose. Reitera-se aqui a idéia cristã de redenção pela morte, constatada em "Jaqueline", "Tísica" e "Tuberculosa".

A identificação entre morte e tuberculose, filtrada por um prisma cristão, é, a meu ver, o ponto de partida para todos os sentidos simbólicos literariamente atribuídos a essa doença, desde o Romantismo até a obra em estudo. Apontando para a morte sem coincidir com ela, a tuberculose institui uma condição intermediária entre a impureza da vida e a pós-vida, a supravida (para utilizar expressão que melhor traduza a hierarquia cristã em que essas duas se organizam). Com um pé no mundo e outro no "além", o tuberculoso é um ser dilacerado, nem integralmente redimido, nem meramente mundano, condenado a oscilar entre dois desejos frustrados: o do gozo físico e o da comunhão plena com o Infinito. Como alternativa consoladora, resta 
a superação artificiosa do "balãozinho" (Idem) (metáfora da poesia?) ou o sofrimento purificante do "cilício" (SOUSA, 1998: 128).

Em alguns momentos, tal situação é identificada à condição humana em si; em outros, à do artista ultra-sensível, que experimenta os dilemas da espécie com tanta intensidade que chega a se converter em espécime único, marginalizado pelos semelhantes. De um modo ou de outro, aqueles dilemas sempre remetem à dicotomia fundamental através da qual a mentalidade cristã enxerga o mundo e o homem, qual seja: pecadolcarne $\backslash$ prazerlvida $X$ santidadelespíritoldorlmorte. Não é de se admirar, por isso, que a imagem da tuberculose, dessa forma instrumentalizada, seja característica de estilos literários de tendência mística, como o Romantismo e o Simbolismo.

\section{O ÚLTIMO TÍSICO}

Manuel Bandeira não pode ser considerado um "poeta pio". Se há religiosidade em sua poesia, ela passa longe de qualquer dogmatismo e não se prende a nenhuma doutrina específica. A importância do cristianismo para a sula poética, entretanto, não se restringe, a meu ver, à mera ligação entre a mentalidade cristã e o comentado estilo humilde de Bandeira, mas abrange os próprios fundamentos dessa poética, determinando-lhe, em considerável medida, a visão de mundo.

Chamar Manuel Bandeira de poeta cristão certamente causará algum choque. Ressaltar a importância da tuberculose em sua poesia, por outro lado, constitui quase que lugar comum e, no entanto, este trabalho acaba de concluir pelo íntimo entrelaçamento entre a imagem da tuberculose e o cristianismo na obra de Bandeira. Da mesma forma, se se aceita com facilidade a ascendência romântico-simbolista desse poeta, é preciso levar em conta a intensa influência exercida pelo cristianismo sobre essas duas escolas antes de torcer o nariz para a idéia de um Bandeira não totalmente secular. A prova disso, como tentei demonstrar, é o uso que o poeta faz da imagem da tuberculose, típica do repertório daquelas escolas, de que ele simplesmente toma posse, com o domínio técnico que lhe é próprio. Nem por isso, ressalte-se, deixa de imprimir-lhe a marca específica de seu tempo, bem como a sua própria. 
Résumé: Cet article analyse l'image de la tuberculose dans la poésie de Manuel Bandeira. Cette image est pensée, dans cet article, non comme une traduction d'une donnée biographique, mais comme donnée esthétique, identifiée avec l'esthétique du romantisme et du symbolisme. L'article analyse la poésie de Manuel Bandeira a partir de deux textes de Cruz e Sousa avec le but de démontrer 1) la filiation romantique et symboliste du poète moderne et 2) l'importance de la mentalité chrétienne chez lui. Pour rapporter le fugue du monde à la pureté (et, par consequence, le monde à l'impureté), la tuberculose apporte l'idée de rédemption par la mort, capitale dans le christianisme.

\section{REFERÊNCIAS BIBLIOGRÁFICAS:}

ARRIGUCCI Jr., Davi. Humildade, paixão e morte. A poesia de Manuel Bandeira. SP: Companhia das Letras, 1991.

ARRIGUCCI Jr., Davi. O cacto e as ruinas. SP: 34 letras, 2000.

BANDEIRA, Manuel. Estrela da vida inteira ( $2^{\mathrm{a}}$ ed). RJ: José Olympio, 1970.

BRAYNER, Sônia (org.). Manuel Bandeira. Fortuna Crítica. RJ: Civilização Brasileira, 1980.

MOURA, Murilo Marcondes de: Manuel Bandeira. São Paulo: Publifolha, 2001.

SONTAG, Susan. A doença como metáfora. RJ: Graal, 1984.

SOUSA, Cruz e. MissallBroquéis. SP: Martins Fontes, 1998. 


\title{
ESCRIBIR LA PASIÓN: EL FISCAL, DE AUGUSTO ROA BASTOS*
}

\author{
Graciela Ravetti** $^{* *}$
}

Resumen: Ensayo sobre la novela $\mathrm{El}$ fiscal, del escritor paraguayo Augusto Roa Bastos, a partir de conceptos, nociones e imágenes aportados por el texto que permiten reflexionar sobre sacrificio, autosacrificio e inmolación en la narrativa emocional de las relaciones entre el poder y el pueblo sometido. Sugiero que la tesis de $\mathrm{El}$ fiscal es la necesidad de quebrar los moralismos por la raiz, lo que trae consecuencias. inusitadas, impredecibles y peligrosas en lo que se refiere a la representación y al lenguaje, a la literatura, a la transmisión de la tradición y, claro, particularmente, a lo que esas nuevas experiencias podrian introducir en el ámbito de lo social, de lo comunitario y de lo nacional. ${ }^{1}$

¿Qué es la moral y cómo tranquilizar a los que se inquietan por su disolución aparente? ¿Qué relaciones se establecen entre algunos tipos de legalidad - reconocidos como tales aunque indirectamente criticados - y nuevas formas de (in)moralidad? ¿Qué responsabilidades nos caben y qué pretextos son necesarios para no enfrentar los desafíos a que ese connubio entre supuesta legalidad y pretendida moral nos desafía? Ese me parece que es el leit motiv de una ficción entre filosófica y política, escrita como una trascripción del sonido y del lenguaje de la pasión y la furia: El fiscal, de Augusto Roa Bastos (1917-2005). Signos, espejismos, performances, delitos, traiciones, todos actos que testimonian estados de conciencia producidos por una atención en tensión permanente, extrema, directa, comprometida y en un proceso de aumento progresivo de intensidad sobre lo que se produce en esos territorios de la nada (en este caso una nación sometida a una dictadura del terror y que carga con el trauma de las guerras iluministas: el Paraguay); territorios que se desatienden y abandonan en nombre de la no intervención,

- Recibido para publicación el 17 de julio de 2006.

" Professora da Faculdade de Letras/UFMG.

' Agradezco al CNPq la Beca de Produtividade em Pesquisa. 